\author{
Jakub Ryśnik \\ https:/ /orcid.org/0000-0001-5994-2922 \\ Akademia Wychowania Fizycznego im. Jerzego Kukuczki w Katowicach \\ Wydział Wychowania Fizycznego \\ Katedra Turystyki i Prozdrowotnej Rekreacji Fizycznej \\ j.rysnik@awf.katowice.pl
}

\title{
IDENTYFIKACJA I OCENA CZYNNIKÓW UCZESTNICTWA KIBICÓW SPORTOWYCH W MIĘDZYNARODOWYCH WIDOWISKACH SPORTOWYCH NA PRZYKŁADZIE BADAŃ KIBICÓW SIATKÓWKI
}

\begin{abstract}
Abstrakt: W artykule przedstawione zostały niepublikowane wyniki badań przeprowadzonych wśród kibiców Mistrzostw Świata w Piłce Siatkowej Mężczyzn w 2014 r. (1618 respondentów bezpośredniego badania kwestionariuszowego). Celem przeprowadzonych studiów było poznanie znaczenia oraz struktury wybranych motywów i barier uczestnictwa w międzynarodowych widowiskach sportowych. Efektem analizy jest uzyskanie informacji o znaczeniu poszczególnych czynników/barier dla respondentów hierarchii ważności czynników oraz modelu czynnikowego wynikającego ze struktury powiązań korelacyjnych pomiędzy zmiennymi wyjaśniającymi uczestnictwo kibiców w międzynarodowych wydarzeniach sportowych.
\end{abstract}

Słowa kluczowe: popyt sportowo-turystyczny, motywy i bariery, turystyka sportowa, międzynarodowe widowiska sportowe, kibice.

\section{WSTEP}

Turystyka sportowa staje się jednym z bardzo dynamicznie rozwijających się rodzajów podróżowania, zwłaszcza $\mathrm{w}$ formie wyjazdów w celu kibicowania podczas międzynarodowych widowisk sportowych (Kazimierczak, Malchrowicz-Mośko, 2013; Standeven, DeKnop, 1999). Hadzik (2014) w swoich pracach wskazuje na potrzebę wyjaśniania tła teoretycznego i rozwoju teorii, która w przypadku tej dziedziny wydaje się nie nadążać za praktyką.

Istotnym problemem jest znajomość uwarunkowań popytu ${ }^{1}$, co determinuje skuteczność menedżerów kształtujących ofertę dla konsumentów. Szczególnie pożądane jest badanie potrzeb i preferencji konsumentów (Kaczmarek, Stasiak, Włodarczyk, 2010; Kramer, 1997).

W nurt ten wpisuje się poznawanie uwarunkowań uczestnictwa konsumentów w międzynarodowych widowiskach sportowych. Celem autora artykułu jest prezentacja niepublikowanych wyników badań o eksploracyjnym charakterze, przeprowadzonych wśród kibiców Mistrzostw Świata w Piłce Siatkowej Mężczyzn w 2014 r. (1618 respondentów bezpośredniego badania kwestionariuszowego). Celem badań było poznanie hierarchii ważności czynników, a także wewnętrznych związków korelacyjnych pomiędzy czynnikami uczestnictwa w międzynarodowych widowiskach sportowych w postaci motywów i barier oraz poszukiwanie związków korelacyjnych między ważnością poszczególnych czynników a zmiennymi demograficznymi badanych kibiców.

\section{PRZEGLĄD LITERATURY}

Czynniki oddziaływające na zjawisko turystyki sportowej mają formę złożoną. W literaturze funkcjonuje wiele zestawień czynników uczestnictwa w dużych wydarzeniach sportowych. Klisiński (2011) wyróżnia czynniki środowiskowe i osobowe analogicznie do uwarunkowań zewnętrznych i wewnętrznych (Pilarczyk, Mruk, 2006). W zakresie czynników wewnętrznych (osobowych) wskazuje się potrzeby, motywy, postrzeganie, postawy, osobowość i uczenie się. Natomiast do zewnętrznych uwarunkowań (środowiskowych) zaliczane są czynniki ekonomiczne (dochody, ceny) oraz społeczno-kulturowe (rodzina, grupy odniesienia, liderzy opinii, grupa społeczna, czynniki kulturowe). 
Tabela 1. Modele czynników udziału kibiców w wydarzeniach sportowych

\begin{tabular}{|c|c|c|}
\hline Autor & Czynniki & $\begin{array}{c}\text { Skala } \\
\text { psychometryczna }\end{array}$ \\
\hline Sloan (1989) & $\begin{array}{l}\text { Efekty zdrowotne, poszukiwanie stresu i stymulacji, katharsis i agresja, rozrywka } \\
\text { i osiągnięcia. }\end{array}$ & - \\
\hline $\begin{array}{l}\text { Milne, McDonald } \\
\text { (1999), za: Won, } \\
\text { Kitamura (2007) } \\
\end{array}$ & $\begin{array}{l}\text { Uwalnianie stresu, doskonalenie umiejętności, estetyka, samoocena, samorealizacja, } \\
\text { rozwój wartości, afiliacja społeczna, przynależność, osiągnięcie, podejmowanie ry- } \\
\text { zyka, agresja, rywalizacja. }\end{array}$ & $\begin{array}{l}\text { MSC - Motivations of } \\
\text { the Sport } \\
\text { Consumer }\end{array}$ \\
\hline $\begin{array}{l}\text { Wann, Schrader, } \\
\text { Wilson (1999), } \\
\text { za: Hadzik (2016) }\end{array}$ & $\begin{array}{l}\text { (1) Motyw związany z potrzebą spędzania czasu wolnego z rodziną i bliskimi, } \\
\text { (2) motyw oparty na stymulacji tzw. pozytywnego stresu (eustress) - kibicowanie sty- } \\
\text { muluje i pobudza do działania oraz jest źródłem rozrywki i przyjemności, (3) mo- } \\
\text { tyw związany z potrzebą przynależności - kibicowanie jest przestrzenią kontaktów } \\
\text { społecznych, (4) motyw oparty na „ucieczce” - uczestnictwo bierne w sporcie po- } \\
\text { zwala na ucieczkę od stresu, problemów życiowych, nudy oraz monotonii życia co- } \\
\text { dziennego, (5) motyw związany z potrzebą podwyższania samooceny kibiców (rea- } \\
\text { lizowany wtedy, gdy dopingowany zespół czy sportowiec wygrywa), (6) motyw } \\
\text { oparty na potrzebie rozrywki w czasie wolnym, (7) motyw związany z potrzebą wi- } \\
\text { dowiskowości, która może być zrealizowana poprzez udział w wielu współcze- } \\
\text { snych wydarzeniach sportowych, zwłaszcza o zasięgu globalnym, (8) motyw eko- } \\
\text { nomiczny oparty na potrzebie osiągnięcia zysków przez fanów robiących zakłady } \\
\text { bukmacherskie. }\end{array}$ & $\begin{array}{l}\text { Sport Fan } \\
\text { Motivation Scale }\end{array}$ \\
\hline Trail, James (2001) & $\begin{array}{l}\text { Osiągnięcia, poznanie (nabywanie wiedzy), estetyka, dramaturgia (eustress), ucieczka, ro- } \\
\text { dzina, atrakcyjność fizyczna sportowców, jakość umiejętności fizycznych sportow- } \\
\text { ców, interakcja społeczna. }\end{array}$ & $\begin{array}{l}\text { MSSC - Motivation } \\
\text { Scale for Sport } \\
\text { Consumption }\end{array}$ \\
\hline Neale, Funk (2006) & Osiągnięcia, zainteresowanie graczami, wartość rozrywkowa, dramaturgia, afiliacja. & $\begin{array}{l}\text { Sport Interest Inven- } \\
\text { tory }\end{array}$ \\
\hline $\begin{array}{l}\text { Funk, Filo, Beaton, } \\
\text { Pritchard (2009) }\end{array}$ & $\begin{array}{l}\text { Socjalizacja, wydajność (poziom efektywności zmagań sportowych), poziom stymu- } \\
\text { lacji / podniecenie, szacunek (sense of achievement level), ucieczka od uciążliwości co- } \\
\text { dziennego życia (level of positive change). }\end{array}$ & $\begin{array}{l}\text { SPEED Model, } \\
\text { Socialization, } \\
\text { Performance, Excite- } \\
\text { ment, Esteem } \\
\text { and Diversion }\end{array}$ \\
\hline Kim, Trail (2010) & $\begin{array}{l}\text { Skala łączy wiele czynników w zakresie: } \\
\text { - motywów wewnętrznych (ucieczka, afiliacja, dokonania, identyfikowanie się z dru- } \\
\text { żyną, a dokładnie z jej społecznością, trenerem, poziomem sportowym, graczami, } \\
\text { dyscypliną sportową, drużyną); } \\
\text { - motywów zewnętrznych (estetyka i dramaturgia, media, reklamy); } \\
\text { - barier wewnętrznych (brak wiedzy, sukcesów, zainteresowania u innych, brak ko- } \\
\text { goś, z kim można oglądać zawody); } \\
\text { - barier zewnętrznych (parking, lokalizacja, uciążliwość, koszty finansowe, alterna- } \\
\text { tywne formy rekreacji, alternatywne formy udziału w sporcie); } \\
\text { - skłonność do takich zachowań, jak: zakup gadżetów z wizerunkiem wspieranych } \\
\text { sportowców oraz udział w wydarzeniach. }\end{array}$ & $\begin{array}{l}\text { SMCSC - Scale for } \\
\text { Motivators } \\
\text { and Constraints } \\
\text { of Sport } \\
\text { Consumption }\end{array}$ \\
\hline
\end{tabular}

Źródło: opracowanie własne.

Pitts i Stotlar (2002), opisując motywy uczestników widowisk sportowych, wymieniają czynniki:

- socjodemograficzne (płeć, wiek, wykształcenie, dochody, odległość od miejsca widowisk);

- ekonomiczne (cena biletu wstępu, cena karnetu, transmisje TV z wydarzeń sportowych, inne dostępne formy spędzania wolnego czasu);

- sportowe (obecność gwiazd w drużynach, styl gry zespołu: ofensywny lub defensywny, poziom rozgrywek, stawka, promocja imprezy, zapowiedzi wielkiego widowiska);

- percepcyjne (dzień tygodnia, w którym odbywa się widowisko, warunki pogodowe, liczba widzów na widowni, przemoc podczas gier).

Z kolei Wojdakowski (2011) wyróżnia takie czynniki uczestnictwa, jak: ranga zawodów, wynik sportowy, efek- towna gra zespołu, poziom techniczno-taktyczny zawodników, emocje oraz związana ze sportem wyczynowym rywalizacja. W literaturze obecny jest także nurt badań oparty na modelu potrzeb człowieka Maslowa, mający na celu znalezienie najlepszego modelu motywacji kibiców sportowych (Waśkowski, 2007, za: Hadzik, Ryśnik, Tomik, 2015) (tab. 1).

Wskazuje się jednak, że użyteczność wielu tych modeli dla praktyków jest ograniczona z uwagi na trudności aplikacji wyników (Funk, Filo, Beaton, Pritchard, 2009). Analizy motywów wyjaśniają rdzeń produktu marketingowego, ale $\mathrm{w}$ mniejszym stopniu stanowią wskazówkę w zakresie pożądanych elementów pozostałych poziomów produktu marketingowego.

Naprzeciw tym oczekiwaniom wychodzą: skala SPEED (Funk, Filo, Beaton, Pritchard, 2009) lub podej- 
ście badawcze zaproponowane przez Kima i Traila (2010) (tab. 1). Łączą one badania motywacji kibiców z innymi polami czynników ich zachowań. Przykładem jest identyfikowanie się z drużyną (Robinson,Trail 2005), kupowanie gadżetów (Trail, Anderson, Fink, 2002), uczestnictwo w wydarzeniach sportowych (Kruger, Saayman, 2012; Trail, Fink, Anderson, 2003), branie w nich udziału w przyszłości, lojalność wobec drużyny (Fink, Trail, Anderson, 2002) oraz popyt na bilety na mecz, mający wpływ na ich ceny (Kemper, Breuer, 2015; Shapiro, Drayer, 2014).

Niezmiernie ważną działalnością kibica jest podróżowanie, z czym wiąże się wiele bodźców sprzyjających uczestnictwu w wydarzeniach sportowych. Szczechowicz postuluje wyjaśnianie swoistej „wspólnej przestrzeni" tworzącej się na styku dziedzin sportu i turystyki i wskazuje na braki w wyjaśnianiu - $\mathrm{z}$ teoretycznego punktu widzenia - związków istniejących między turystyką i sportem (Szczechowicz, 2015, s. 41). Stawiane jest np. pytanie, czy turystyka i sport generują pewne wartości unikatowe i ujawniające się w swoistym efekcie synergicznym (Weed, 2008, za: Szczechowicz, 2015). Odpowiadają na nie m.in. Weed i Bull (2004), Smith i Stewart (2007) oraz Ryśnik, Żylak i Tomik (2018), którzy uważają, że sport i turystyka mają wiele wspólnego. Hadzik, Ryśnik i Tomik (2015) stwierdzają, że uczestnictwo w widowiskach sportowych jest również zdeterminowane konkretnymi uwarunkowaniami atrakcyjności turystycznej wydarzenia i miejsca. Dla kibiców mogą być ważne takie elementy, jak: możliwość zwiedzania podczas podróżowania (atrakcji przyrodniczych, zabytków kultury, muzeów, atrakcji kulturalnych o charakterze sportowo-rekreacyjnym), korzystanie z obiektów sportowo-rekreacyjnych, możliwość tzw. nocnego życia z szeroką ofertą rozrywkową oraz uczestnictwa także w innych imprezach niż sportowe (Hadzik, Ryśnik, Tomik, 2015).

Udział w wydarzeniach sportowych zależy również od kształtowania się zjawisk o charakterze destymulantów, czy inaczej barier. Znaczenie mają przeszkody ekonomiczne (Hadzik, Bartik, 2012; Wojdakowski, 2008), które są uzależnione od konieczności poniesienia wydatków na bilet wstępu na wydarzenie, transport, nocleg, wyżywienie, a także dodatkowe usługi, np. rozrywkowe. Przeszkodą może być również brak elastyczności w dysponowaniu innymi zasobami, takimi jak czas wolny, gdy terminy meczów są niesprzyjające (Wojdakowski, 2011). Przykłady badań nad czynnikami podróżowania w celu uczestnictwa w turystyce sportowej zaprezentowano w tab. 2.

Zastosowany $\mathrm{w}$ badaniach opisanych $\mathrm{w}$ artykule zestaw zmiennych został dobrany na podstawie przedstawionej literatury w oparciu o trzy przesłanki: (1) wszechstronne badanie oddziaływania połączonych przestrzeni sportu i turystyki, (2) użycie stymulantów i destymulantów (barier), (3) badanie zjawisk, na które mogą mieć wpływ decyzje menedżerów produktów sportowo-turystycznych.

Tabela 2. Modele czynników podróżowania w celu uczestnictwa w wydarzeniach sportowych

\begin{tabular}{|c|c|}
\hline Autorzy & Czynniki/bariery \\
\hline $\mathrm{Yu}(2010)$ & $\begin{array}{l}\text { Koszty, łatwość aranżowania planów podróży, zainteresowanie sportem profesjonalnym, } \\
\text { chęć doświadczenia innej kultury, zainteresowanie podróżami, doświadczenie oglądania } \\
\text { wydarzeń sportowych na żywo w przeszłości oraz szansa zobaczenia słynnych graczy. }\end{array}$ \\
\hline Mohan, Thomas (2012) & $\begin{array}{l}\text { Na decyzje dotyczące podróży wpływają: } \\
\text { - odległość, } \\
\text { - planowanie meczów (np. weekendy lub dni tygodnia), } \\
\text { - czas spędzony w podróży, } \\
\text { - koszt zakwaterowania (w większym stopniu niż koszt transportu), } \\
\text { - wymagane godziny podróży, } \\
\text { - środek transportu. }\end{array}$ \\
\hline Fairley (2009) & Środek transportu jako narzędzie służące do budowania tożsamości grupy. \\
\hline Ahn, Lee (2014) & $\begin{array}{l}\text { Liczba zwycięstw drużyny jako gospodarza w rozgrywkach ligowych, rozmiar i jakość sta- } \\
\text { dionu oraz style gry. }\end{array}$ \\
\hline Surdam (2009) & $\begin{array}{l}\text { Pozacenowe determinanty popytu na poszczególne gry: dzień tygodnia, jakość przeciwnika } \\
\text { i wydarzenia specjalne. }\end{array}$ \\
\hline $\begin{array}{l}\text { Simmons, Popp, McEvoy, Howell } \\
\text { (2018) }\end{array}$ & $\begin{array}{l}\text { Bariery uczestnictwa: zobowiązania związane ze szkołą i pracą, koszty napojów, słaby po- } \\
\text { ziom zespołu, możliwość obejrzenia rozgrywek w telewizji, ograniczenia czasowe, brak za- } \\
\text { interesowanie daną dyscypliną. }\end{array}$ \\
\hline Nishio (2014) & $\begin{array}{l}\text { Skala ograniczeń dla międzynarodowych podróżujących fanów sportu złożona z następują- } \\
\text { cych czynników: alternatywne możliwości spędzania wolnego czasu, bezpieczeństwo, brak } \\
\text { atrakcyjności turystycznej, odmienna kultura, towarzystwo i odległość. }\end{array}$ \\
\hline $\begin{array}{l}\text { Anthony, Kahn, Madison, Paul, } \\
\text { Weinbach (2014) }\end{array}$ & $\begin{array}{l}\text { Koszty, łatwość aranżowania planów podróży, zainteresowanie sportem profesjonalnym, } \\
\text { chęć doświadczenia innej kultury, zainteresowanie podróżami, doświadczenie oglądania } \\
\text { wydarzeń sportowych na żywo w przeszłości oraz szansa zobaczenia słynnych graczy. }\end{array}$ \\
\hline
\end{tabular}

Źródło: opracowanie własne. 


\section{METODA I ORGANIZACJA BADAŃ}

Badania prowadzone były metodą anonimowego sondażu diagnostycznego na dobranej celowo grupie kibiców, obecnych na meczach Mistrzostw Świata w Piłce Siatkowej Mężczyzn 2014 (MŚPSM 2014) (w sierpniu i we wrześniu) w hali widowiskowo-sportowej Spodek w Katowicach ${ }^{2}$. Badania przeprowadzano w momencie gromadzenia się widzów w hali przed meczami. Polegały one na samodzielnym wypełnieniu kwestionariusza przez kibica.

Zmienne zastosowane w badaniach obejmowały następujące cechy (mierzone skalą sześciostopniową: od „nieważny czynnik / nieważna bariera” - 0, do „,bardzo ważny czynnik / ważna bariera" - 5):

- ważność barier uczestnictwa w meczach reprezentacji siatkarskiej,

- ważność czynników uczestnictwa w meczach reprezentacji siatkarskiej,

- ważność dodatkowych usług rekreacyjno-turystycznych towarzyszących meczom reprezentacji siatkarskiej.

W ankiecie pytano również o zmienne demograficzno-społeczno-ekonomiczne badanych, tj.: płeć, wiek, wykształcenie, status zawodowy, wielkość miejscowości zamieszkania i dochód. Badanie pozwoliło również na rozróżnienie kibiców krajowych i zagranicznych (pochodzenie).

Przystępując do badań, sformułowano następujące hipotezy badawcze:

Hipoteza 1. Ocena ważności poszczególnych czynników uczestnictwa $w$ wydarzeniach sportowych różni się w zależności od charakteryzujących respondentów cech, takich jak:

- płeć,

- pochodzenie (Polska/zagranica).

Hipoteza 2. Oceny ważności poszczególnych czynników uczestnictwa w wydarzeniach sportowych różnią się między sobą, tworząc hierarchie.

Hipoteza 3. Poszczególne oceny czynników uczestnictwa $\mathrm{w}$ wydarzeniach sportowych pozostają $\mathrm{w}$ korelacji z cechami demograficznymi charakteryzującymi respondentów, takimi jak: wiek, wykształcenie, status zawodowy, dochód, stan cywilny oraz pochodzenia (Polska/zagranica).

Hipoteza 4. Analizując wielowymiarowe korelacje w zakresie zmiennych stanowiących czynniki uczestnictwa w wydarzeniach sportowych, można wyróżnić czynniki ukryte, wykorzystując metodę eksploracyjnej analizy czynnikowej.

Obliczenia wykonano głównie za pomocą aplikacji SAS. Enterprise Guide 6.1. Posiłkowano się oprogramowaniem MS Excel 2010 oraz w niektórych przypadkach skorzystano z pakietu STATISTICA 13.1.

\section{CHARAKTERYSTYKA PRÓBY BADAWCZEJ}

Baza danych utworzona $\mathrm{w}$ wyniku przeprowadzonych badań obejmuje informacje pozyskane od 1618 respondentów. Liczba ta jest większa niż oszacowana minimalna liczebność próby uwzględniającej wielkość próby generalnej (przy błędzie 5\% dla próby generalnej około 50 tys. kibiców tego wydarzenia ${ }^{3}$ oraz poziomie ufności 0,95 minimalna liczebność próby to 381 respondentów) (Steczkowski, 1995).

Respondenci pochodzili przede wszystkim z Polski (1478 osób - 91,34\%). W badanej grupie przeważali mężczyźni (55,98\%) (tab.3), mieszkający w miastach liczących od 50 do 99 tys. mieszkańców (tab. 4). Najliczniejsi wśród badanych są kibice w grupach wiekowych od 19 do 25 lat oraz od 26 do 35 lat (tab. 4).

Tabela 3. Płeć i pochodzenie badanych kibiców

\begin{tabular}{|l|l|c|c|c|c|}
\cline { 3 - 6 } \multicolumn{2}{c|}{} & \multicolumn{4}{c|}{ Liczba odpowiedzi } \\
\cline { 3 - 7 } \multicolumn{2}{c|}{} & kobiety & mężczyźni & brak & razem \\
\hline $\begin{array}{l}\text { Miejsce } \\
\text { zamieszkania } \\
\text { kibiców }\end{array}$ & Polska & 642 & 819 & 17 & 1478 \\
\cline { 2 - 6 } & Zagranica & 61 & 75 & 4 & 140 \\
\hline Razem & 703 & 894 & 21 & 1618 \\
\hline
\end{tabular}

Źródło: opracowanie własne z użyciem pakietu SAS.

Tabela 4. Wielkość miejscowości zamieszkania (ze względu na liczbę ludności), wiek i wykształcenie respondentów

\begin{tabular}{|c|c|c|}
\hline \multirow{2}{*}{$\begin{array}{c}\text { Wielkość } \\
\text { miejscowości } \\
\text { zamieszkania }\end{array}$} & \multicolumn{2}{|c|}{ Kibice } \\
\hline & liczebność & odsetek (\%) \\
\hline Do 10 tys. osób & 327 & 20,85 \\
\hline 11-49 tys. & 367 & 23,41 \\
\hline 50-99 tys. & 499 & 31,82 \\
\hline $100-499$ tys. & 286 & 18,24 \\
\hline 500-999 tys. & 69 & 4,40 \\
\hline$>1 \mathrm{mln}$ & 20 & 1,28 \\
\hline \multicolumn{3}{|c|}{ liczba braku danych $=50$} \\
\hline Grupa wiekowa & liczebność & odsetek (\%) \\
\hline Mniej niż 19 lat & 219 & 13,82 \\
\hline 19-25 lat & 652 & 41,14 \\
\hline 26-35 lat & 405 & 25,55 \\
\hline $36-45$ lat & 185 & 11,67 \\
\hline 46-55 lat & 89 & 5,62 \\
\hline 56-65 lat & 28 & 1,77 \\
\hline 66 i więcej lat & 7 & 0,44 \\
\hline \multicolumn{3}{|c|}{ liczba braku danych $=33$} \\
\hline Wykształcenie & liczebność & odsetek (\%) \\
\hline Podstawowe & 136 & 8,62 \\
\hline Zawodowe & 146 & 9,25 \\
\hline Średnie & 481 & 30,48 \\
\hline Niepełne wyższe & 238 & 15,08 \\
\hline Wyższe & 577 & 36,57 \\
\hline
\end{tabular}

Źródło: opracowanie własne z użyciem pakietu SAS. 
Tabela 5. Status społeczno-zawodowy badanych kibiców

\begin{tabular}{|l|c|c|c|c|c|}
\cline { 2 - 6 } \multicolumn{1}{c|}{} & \multicolumn{5}{c|}{ Status społeczno-zawodowy } \\
\cline { 2 - 6 } \multicolumn{1}{c|}{} & pracujący & $\begin{array}{c}\text { niepra- } \\
\text { cujący }\end{array}$ & emeryt & rencista & $\begin{array}{c}\text { uczeń/ } \\
\text { student }\end{array}$ \\
\hline $\begin{array}{l}\text { Liczeb- } \\
\text { ność }\end{array}$ & 918 & 233 & 33 & 13 & 509 \\
\hline $\begin{array}{l}\text { Udział } \\
(\%)\end{array}$ & 56,74 & 14,40 & 2,04 & 0,80 & 31,46 \\
\hline & \multicolumn{5}{|c|}{ Stan cywilny } \\
\cline { 2 - 6 } & \multicolumn{2}{|c|}{$\begin{array}{c}\text { kawaler/ } \\
\text { panna }\end{array}$} & $\begin{array}{c}\text { żonaty/ } \\
\text { zamężna }\end{array}$ & $\begin{array}{c}\text { rozwie- } \\
\text { dziony(a) }\end{array}$ & $\begin{array}{c}\text { wdowiec/ } \\
\text { wdowa }\end{array}$ \\
\hline $\begin{array}{l}\text { Liczeb- } \\
\text { ność }\end{array}$ & 1031 & 490 & 32 & 8 \\
\hline $\begin{array}{l}\text { Udział } \\
(\%)\end{array}$ & 63,72 & 30,28 & 1,98 & 0,49 \\
\hline
\end{tabular}

Źródło: opracowanie własne z użyciem pakietu SAS.

Wśród ankietowanych przeważały osoby z wyższym wykształceniem (tab. 3). Dużą część badanej grupy stanowili pracujący oraz uczący się (tab. 5). W większości były to osoby stanu wolnego (tab. 5).

\section{WYNIKI (ANALIZA STRUKTURALNA)}

Rozkład uzyskanych ocen ważności (tab. 6) wskazuje na największą uciążliwość barier w postaci kosztów związanych z wyjazdem na imprezę międzynarodową oraz konieczność wygospodarowania wolnego czasu. Najmniej ważną barierę dla respondentów stanowiły względy bezpieczeństwa w trakcie podróży na mecz i w czasie jego trwania.

Badając istotność różnic w zakresie wartości średnich dla poszczególnych barier, można uporządkować jej hierarchię ważności, co zaprezentowano w tab. 7 .

W analogiczny sposób mierzono ważność grupy zmiennych czynników (stymulantów) uczestnictwa kibiców w wydarzeniach sportowych (tab. 8) i sprawdzono uzyskany obraz hierarchii ważności tych czynników. Najważniejszym czynnikiem w zakresie analizowanej wiązki zmiennych jest możliwość udziału na żywo w wydarzeniu. Najmniej ważny okazał się prestiż meczu (tab. 9).

W zakresie czynników określających ważność dodatkowej, typowo turystycznej oferty badani kibice cenili sobie przede wszystkim ewentualną możliwość uczestnictwa dodatkowo w innej niż sportowa imprezie, np. w koncercie (tab. 10, 11).

\subsection{ANALIZA ZRÓŻNICOWANIA OCEN WAŻNOŚCI Z UWAGI NA PŁEĆ I POCHODZENIE}

W tab. 12 zostały przedstawione wyniki analizy istotności różnic miary średniej, charakteryzującej rozkłady odpowiedzi ze względu na płeć, wraz z interpretacją wyników.

W tab. 13 przedstawiono wyniki analizy istotności różnic miary średniej, charakteryzującej rozkłady odpowiedzi ze względu na pochodzenie kibiców.

Tabela 6. Miary charakteryzujące rozkład odpowiedzi respondentów

\begin{tabular}{|l|l|c|c|c|c|c|c|}
\hline \multicolumn{1}{|c|}{ Zmienna } & \multicolumn{1}{|c|}{ Opis } & Średnia & $\begin{array}{c}\text { Odchylenie } \\
\text { standardowe }\end{array}$ & Moda & N & N braków & Mediana \\
\hline 3.1. Termin & Terminy meczów ograniczają kibicowanie & 2,287 & 1,613 & 3 & 1604 & 14 & 3 \\
\hline 3.2. Koszty & Koszty wyjazdu na mecze siatkówki & $\mathbf{3 , 0 1 6}$ & 1,490 & 3 & 1606 & 12 & 3 \\
\hline 3.3. Bhp & $\begin{array}{l}\text { Obawa o bezpieczeństwo podczas wyjazdu } \\
\text { i meczu }\end{array}$ & 1,547 & 1,557 & 0 & 1595 & 23 & 1 \\
\hline 3.4. Promocja & $\begin{array}{l}\text { Niewłaściwa promocja meczów reprezenta- } \\
\text { cyjnych }\end{array}$ & 2,031 & 1,693 & 0 & 1598 & 20 & 2 \\
\hline 3.5. Zakup & Kupno biletów na mecze & $\mathbf{2 , 7 7 6}$ & 1,644 & 3 & 1596 & 22 & 3 \\
\hline 3.6. Oferta & Oferta na samych meczach & 2,195 & 1,597 & 3 & 1581 & 37 & 2 \\
\hline 3.7. Czas & Brak wolnego czasu & $\mathbf{2 , 8 0 1}$ & 1,651 & 4 & 1594 & 24 & 3 \\
\hline 3.8. Inne & Inne & 1,364 & 1,948 & 0 & 165 & 1453 & 0 \\
\hline
\end{tabular}

Źródło: opracowanie własne z użyciem pakietu SAS.

Tabela 7. Hierarchia ważności barier uczestnictwa kibiców w meczach (pytanie 3)

\begin{tabular}{|l|c|c|c|c|c|c|c|}
\hline \multirow{2}{*}{ Wyszczególnienie } & \multicolumn{9}{c|}{ Zmienna } \\
\cline { 2 - 9 } & 3.2 koszty & 3.7. czas & 3.5. zakup & 3.1. termin & 3.6. oferta & 3.4. promocja & 3.3. bhp \\
\hline Średnia ocena & 3,02 & 2,80 & 2,78 & 2,29 & 2,20 & 2,03 & 1,55 \\
\hline Miejsce w hierarchii & $\mathbf{1 .}$ & \multicolumn{2}{|c|}{$\mathbf{2 .}$} & \multicolumn{2}{|c|}{$\mathbf{3 .}$} & $\mathbf{4 .}$ & $\mathbf{5 .}$ \\
\hline
\end{tabular}


Tabela 8. Miary charakteryzujące rozkład odpowiedzi dotyczących czynników uczestnictwa kibiców

\begin{tabular}{|l|l|c|c|c|c|c|c|}
\hline \multicolumn{1}{|c|}{ Zmienna } & \multicolumn{1}{|c|}{ Opis } & Średnia & $\begin{array}{c}\text { Odchylenie } \\
\text { standardowe }\end{array}$ & Moda & N & $\begin{array}{c}\text { N } \\
\text { braków }\end{array}$ & Mediana \\
\hline 7.1. Rodzaj & Rodzaj rozgrywek (np. Mistrzostwa Europy) & $\mathbf{3 , 8 9 2}$ & 1,340 & 5 & 1593 & 25 & 4 \\
\hline 7.2. Walka & Możliwość zaciętej walki sportowej & $\mathbf{3 , 8 7 5}$ & 1,179 & 5 & 1605 & 13 & 4 \\
\hline 7.3. Marka & Marka (sława) drużyn rywalizujących & 3,637 & 1,324 & 4 & 1597 & 21 & 4 \\
\hline 7.4. Relaks & Relaks, rozrywka & $\mathbf{3 , 8 9 8}$ & 1,205 & 5 & 1603 & 15 & 4 \\
\hline 7.5. Na żywo & Chęć oglądania meczu na żywo & $\mathbf{4 , 1 3 9}$ & 1,085 & 5 & 1604 & 14 & 4 \\
\hline 7.6. Prestiż & Prestiż bycia kibicem reprezentacji & 2,988 & 1,687 & 5 & 1602 & 16 & 3 \\
\hline 7.7. Stawka & Stawka meczu & 3,305 & 1,440 & 3 & 1601 & 17 & 3 \\
\hline 7.8. Poziom & Przewidywany poziom sportowy & 3,636 & 1,162 & 4 & 1602 & 16 & 4 \\
\hline 7.9. Gwiazda & Zobaczenie na żywo gwiazdy siatkówki & 3,802 & 1,261 & 5 & 1599 & 19 & 4 \\
\hline 7.10. Rodzina & Możliwość pójścia na mecz z bliskimi & 3,788 & 1,228 & 5 & 1603 & 15 & 4 \\
\hline 7.11. Miejsce & Miejsce rywalizacji (meczu) & 3,557 & 1,355 & 5 & 1597 & 21 & 4 \\
\hline 7.12. Inne & Inne wskazane & 1,440 & 1,939 & 0 & 116 & 1502 & 0 \\
\hline
\end{tabular}

Źródło: opracowanie własne z użyciem pakietu SAS.

Tabela 9. Hierarchia ważności czynników uczestnictwa w meczach w opinii kibiców

\begin{tabular}{|c|c|c|c|c|c|c|c|c|c|c|c|}
\hline \multirow[b]{2}{*}{ Wyszczególnienie } & \multicolumn{11}{|c|}{ Zmienna } \\
\hline & 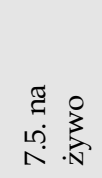 & 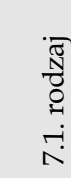 & $\begin{array}{l}\tilde{\widetilde{\sigma}} \\
\overrightarrow{\widetilde{\sigma}} \\
3 \\
\stackrel{3}{N}\end{array}$ & 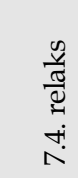 & م. & 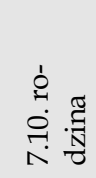 & 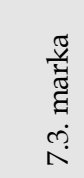 & 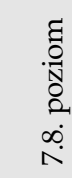 & 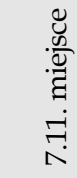 & $\begin{array}{l}\frac{\pi}{\pi} \\
\frac{\pi}{3} \\
\frac{\pi}{\omega} \\
\stackrel{0}{1}\end{array}$ & 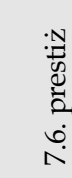 \\
\hline Średnia ocena & 4,14 & 3,89 & 3,87 & 3,90 & 3,80 & 3,79 & 3,64 & 3,64 & 3,56 & 3,30 & 2,99 \\
\hline Miejsce w hierarchii & 1. & \multicolumn{5}{|c|}{2.} & 3. & \multicolumn{2}{|c|}{4.} & 5. & 6. \\
\hline
\end{tabular}

Źródło: opracowanie własne z użyciem pakietu STATISTICA.

Tabela 10. Miary charakteryzujące rozkład zmiennych określających ważność dla kibiców dodatkowej, typowo turystycznej oferty

\begin{tabular}{|l|l|c|c|c|c|c|c|}
\hline \multicolumn{1}{|c|}{ Zmienna } & \multicolumn{1}{|c|}{ Opis } & Średnia & $\begin{array}{c}\text { Odchylenie } \\
\text { standardowe }\end{array}$ & Moda & N & N braków & Mediana \\
\hline 8.1. Rekreacja, sport & rekreacja fizyczna, sport & 2,160 & 1,655 & 0 & 1521 & 97 & 2 \\
\hline 8.2. Przyroda & atrakcje przyrodnicze & 2,067 & 1,521 & 3 & 1601 & 17 & 2 \\
\hline 8.3. Rozrywka & oferta rozrywkowa & $\mathbf{2 , 3 5 4}$ & 1,608 & 3 & 1592 & 26 & 3 \\
\hline 8.4. Kultura & atrakcje kulturowe & $\mathbf{2 , 4 2 0}$ & 1,541 & 3 & 1605 & 13 & 3 \\
\hline 8.5. Imprezy & imprezy dodatkowe & $\mathbf{2 , 5 9 1}$ & 1,525 & 3 & 1605 & 13 & 3 \\
\hline 8.6. Inne & inne & 1,349 & 1,918 & 0 & 146 & 1,472 & 0 \\
\hline
\end{tabular}

Źródło: opracowanie własne z użyciem pakietu SAS.

Tabela 11. Hierarchia ważności czynników w zakresie dodatkowej, typowo turystycznej oferty dla kibiców

\begin{tabular}{|l|c|c|c|c|c|}
\hline \multirow{2}{*}{\multicolumn{1}{c|}{ Wyszczególnienie }} & \multicolumn{5}{c|}{ Zmienna } \\
\cline { 2 - 6 } & 8.5. imprezy & 8.3. rozrywka & 8.4. kultura & 8.1. rekreacja, sport & 8.2. przyroda \\
\hline Średnia ocena & 2,59 & 2,35 & 2,42 & 2,16 & 2,07 \\
\hline Miejsce w hierarchii & 1. & \multicolumn{2}{|c|}{2.} & 3. & 4. \\
\hline
\end{tabular}

Źródło: opracowanie własne.

W zakresie barier polscy kibice $\mathrm{w}$ większym stopniu zwrócili uwagę na problem kosztów wyjazdu (wyjazd + bilet) na imprezę sportową. Dla gości z zagranicy większe znaczenie ma poczucie bezpieczeństwa oraz odpowiednia promocja wydarzenia. W odniesieniu do czynników stymulantów w badanej grupie można stwier- dzić, że polscy kibice MŚPSM 2014 w porównaniu z uczestnikami takich wydarzeń z zagranicy wskazywali praktycznie wszystkie wymienione czynniki. Jedynie dostęp do oferty dodatkowej - rekreacyjnej, sportowej, kulturalnej - wyłącznie kibice zagraniczni uznawali za ważny. 
Tabela 12. Ocena istotności różnic odpowiedzi ze względu na płeć kibiców

\begin{tabular}{|c|c|c|c|c|}
\hline \multirow{3}{*}{ Zmienna } & \multicolumn{4}{|c|}{ Zróżnicowanie ze względu na płeć } \\
\hline & \multicolumn{2}{|c|}{ średnia dla } & \multirow{2}{*}{$p^{\mathrm{a}}$} & \multirow{2}{*}{$\begin{array}{c}\text { interpretacja } \\
\text { bariera/czynnik istotniejszy dla }\end{array}$} \\
\hline & kobiet & mężczyzn & & \\
\hline 3.1. Termin & 2,178 & 2,382 & $0,012^{\mathrm{a}}$ & mężczyzn \\
\hline 3.2. Koszty & 3,109 & 2,960 & $0,040^{\mathrm{a}}$ & kobiet \\
\hline 3.3. Bhp & 1,492 & 1,596 & 0,154 & brak istotnej różnicy \\
\hline 3.4. Promocja & 1,912 & 2,135 & $0,009^{\mathrm{a}}$ & mężczyzn \\
\hline 3.5. Zakup & 2,722 & 2,834 & 0,180 & brak istotnej różnicy \\
\hline 3.6. Oferta & 2,052 & 2,309 & $0,001^{\mathrm{a}}$ & mężczyzn \\
\hline 3.7. Czas & 2,617 & 2,948 & $0,000^{\mathrm{a}}$ & mężczyzn \\
\hline 3.8. Inne & 1,107 & 1,558 & 0,188 & brak istotnej różnicy \\
\hline 7.1. Rodzaj & 3,783 & 3,979 & $0,028^{\mathrm{a}}$ & mężczyzn \\
\hline 7.2. Walka & 3,790 & 3,938 & $0,045^{\mathrm{a}}$ & mężczyzn \\
\hline 7.3. Marka & 3,458 & 3,789 & $1,3214534 \mathrm{E}-6^{\mathrm{a}}$ & mężczyzn \\
\hline 7.4. Relaks & 3,987 & 3,832 & $0,007^{\mathrm{a}}$ & kobiet \\
\hline 7.5. Na żywo & 4,264 & 4,037 & $0,000032^{\mathrm{a}}$ & kobiet \\
\hline 7.6. Prestiż & 2,810 & 3,129 & $0,00059^{a}$ & kobiet \\
\hline 7.7. Stawka & 3,110 & 3,461 & $5,113981 E-6^{a}$ & mężczyzn \\
\hline 7.8. Poziom & 3,529 & 3,722 & $0,004^{\mathrm{a}}$ & mężczyzn \\
\hline 7.9. Gwiazda & 3,831 & 3,775 & 0,291 & brak istotnej różnicy \\
\hline 7.10. Rodzina & 3,784 & 3,791 & 0,757 & brak istotnej różnicy \\
\hline 7.11. Miejsce & 3,503 & 3,611 & $0,095^{\mathrm{a}}$ & mężczyzn \\
\hline 7.12. Inne & 1,208 & 1,525 & 0,253 & brak istotnej różnicy \\
\hline 8.1. Rekreacja, sport & 2,027 & 2,268 & $0,004^{a}$ & mężczyzn \\
\hline 8.2. Przyroda & 2,044 & 2,095 & 0,505 & brak istotnej różnicy \\
\hline 8.3. Rozrywka & 2,267 & 2,431 & $0,041^{\mathrm{a}}$ & mężczyzn \\
\hline 8.4. Kultura & 2,469 & 2,390 & 0,276 & brak istotnej różnicy \\
\hline 8.5. Imprezy & 2,723 & 2,490 & $0,001^{\mathrm{a}}$ & kobiet \\
\hline \begin{tabular}{|l|} 
8.6. Inne \\
\end{tabular} & 1,471 & 1,219 & 0,514 & brak istotnej różnicy \\
\hline
\end{tabular}

Objaśnienia: a $p$ obliczona dla testu Wilcoxona zróżnicowania średnich; istotność, gdy $p<0,05$.

Źródło: opracowanie własne z użyciem pakietu SAS.

Tabela 13. Ocena istotności różnic odpowiedzi ze względu na pochodzenie kibiców

\begin{tabular}{|l|c|c|c|c|}
\hline \multirow{2}{*}{ Zmienna } & \multicolumn{2}{|c|}{ Zróżnicowanie ze względu na płé́ } \\
\cline { 2 - 4 } & \multicolumn{2}{|c|}{ Średnia dla kibiców } & \multicolumn{2}{c|}{$\begin{array}{c}\text { interpretacja } \\
\text { bariera/czynnik istotniejszy } \\
\text { dla kibiców }\end{array}$} \\
\cline { 2 - 5 } & z Polski & z zagranicy & & brak istotnej różnicy \\
\hline 3.1.Termin & 2,292 & 2,237 & 0,803 & z Polski \\
\hline 3.2. Koszty & 3,084 & 2,297 & $2,9500759 \mathrm{E}-8$ & z zagranicy \\
\hline 3.3. Bhp & 1,502 & 2,022 & 0,001 & zagranicy \\
\hline 3.4. Promocja & 2,001 & 2,356 & 0,012 & z Polski \\
\hline 3.5. Zakup & 2,828 & 2,215 & 0,000066 & brak istotnej różnicy \\
\hline 3.6. Oferta & 2,201 & 2,131 & 0,695 & brak istotnej różnicy \\
\hline 3.7. Czas & 2,796 & 2,848 & 0,958 & brak istotnej różnicy \\
\hline 3.8. Inne & 1,329 & 1,560 & 0,376 & z Polski \\
\hline 7.1. Rodzaj & 3,890 & 3,914 & 0,241 & z Polski \\
\hline 7.2. Walka & 3,899 & 3,620 & 0,0006 & z Polski \\
\hline 7.3. Marka & 3,684 & 3,146 & $2,7934413 \mathrm{E}-8$ & z Polski \\
\hline 7.4. Relaks & 3,963 & 3,216 & $4,078027 \mathrm{E}-12$ & brak istotnej różnicy \\
\hline 7.5. Na żywo & 4,169 & 3,827 & 0,00002 & z Polski \\
\hline 7.6. Prestiż & 2,977 & 3,095 & 0,985 & z Polski \\
\hline 7.7. Stawka & 3,336 & 2,971 & 0,001 & z Polski \\
\hline 7.8. Poziom & 3,674 & 3,228 & $1,0761468 \mathrm{E}-6$ & \\
\hline 7.9. Gwiazda & 3,845 & 3,343 & $3,246329 \mathrm{E}-7$ & \\
\hline
\end{tabular}


Tabela 13 (cd.)

\begin{tabular}{|c|c|c|c|c|}
\hline \multirow{3}{*}{ Zmienna } & \multicolumn{4}{|c|}{ Zróżnicowanie ze względu na płeć } \\
\hline & \multicolumn{2}{|c|}{ Średnia dla kibiców } & \multirow[b]{2}{*}{$p^{\mathrm{a}}$} & \multirow{2}{*}{$\begin{array}{c}\text { interpretacja } \\
\text { bariera/czynnik istotniejszy } \\
\text { dla kibiców }\end{array}$} \\
\hline & z Polski & z zagranicy & & \\
\hline 7.10. Rodzina & 3,811 & 3,543 & 0,003 & z Polski \\
\hline 7.11. Miejsce & 3,582 & 3,292 & 0,012 & Z Polski \\
\hline 7.12. Inne & 1,392 & 1,684 & 0,668 & brak istotnej różnicy \\
\hline 8.1. Rekreacja, sport & 2,128 & 2,534 & 0,006 & z zagranicy \\
\hline 8.2. Przyroda & 2,019 & 2,584 & 0,00002 & z zagranicy \\
\hline 8.3. Rozrywka & 2,341 & 2,504 & 0,231 & brak istotnej różnicy \\
\hline 8.4. Kultura & 2,364 & 3,007 & 2,4180173E-6 & z zagranicy \\
\hline 8.5. Imprezy & 2,592 & 2,580 & 0,794 & brak istotnej różnicy \\
\hline 8.6. Inne & 1,283 & 1,789 & 0,242 & brak istotnej różnicy \\
\hline
\end{tabular}

Objaśnienia: a $p$ obliczona dla testu Wilcoxona zróżnicowania średnich; istotność, gdy $p<0,05$.

Źródło: opracowanie własne z użyciem pakietu SAS.

\subsection{ANALIZA KORELACJI BADANYCH ZMIENNYCH}

Wykorzystując analizę zależności jednowymiarowej, dokonano analizy istotnych korelacji z tzw. zmiennymi metryczkowymi. Interpretacji poddano związki o współczynniku korelacji większym niż 0,2 lub mniejszym niż $-0,2$ (zob. tab. 14).

W zakresie zmiennych metryczkowych wykryte związki są intuicyjne i stanowią potwierdzenie oczywistych prawidłowości zachodzących w społeczeństwie. Zaobserwowano korelację dodatnią wieku badanych $z$ dochodami respondentów, ich statusem zawodowym i wykształceniem. Wyższy poziom wykształcenia współzależy bowiem dodatnio od posiadania pracy. Status zawodowy ma związek $\mathrm{z}$ wiekiem, wykształceniem oraz dochodem badanych. Ciekawy związek istnieje między poziomem dochodu a ważnością bariery $\mathrm{w}$ postaci niedogodnych terminów meczów $(0,205)$, a także między wiekiem badanych a ważnością bariery w postaci braku wolnego czasu $(0,202)$.

\subsection{EKSPLORACYJNA ANALIZA CZYNNIKOWA ZBIORU DANYCH}

Eksploracyjną analizę czynnikową zastosowano w celu poznania wielowymiarowych powiązań między poszczególnymi zmiennymi modelu badanych zmiennych opisujących predyspozycje badanych do uczestnictwa w widowiskach sportowych (barier, czynników oraz czynników dodatkowych w turystyce). Zbiór danych spełnia wiele warunków początkowych, które powinny być spełnione, aby można było mówić o zgodnych z metodologią wynikach analizy czynnikowej. Zbiór ten jest większy niż zalecana w literaturze minimalna próba, tj. 100 (Barret, Kline, 1981, za: Zakrzewska, 1994) lub 200 (Comrey, 1978, za: Zakrzewska, 1994). Współczynnik Alfa Cronbacha na poziomie wysokim, wskazującym na rzetelność zastosowanych skal $(0,824)$. Miara KMO wykazuje poziom świadczący o tym, że korelacje pomiędzy parami zmiennych mogą być wyjaśnione poprzez inne zmienne (MSA $=0,85709256)^{4}$. Wynik testu

Tabela 14. Wykryte związki korelacyjne o współczynniku Rho Spearmana mniejszym od -0,2 lub większym od 0,2 przy poziomie istotności 0,05

\begin{tabular}{|l|c|c|c|c|c|c|c|}
\hline \multirow{2}{*}{ Wyszczególnienie } & \multirow{2}{*}{ Wiek } & \multirow{2}{*}{ Wykształcenie } & \multirow{2}{*}{ Status: pracuje } & \multicolumn{2}{c|}{ Dochód w } & \multicolumn{2}{c|}{ Zmienne } \\
\cline { 5 - 8 } & & & & PLN & euro & 3.1. termin & 3.7. czas \\
\hline Wiek & 1 & 0,315 & 0,382 & 0,472 & 0,399 & \\
\hline Wykształcenie & & 1 & 0,262 & & & & 0,202 \\
\hline Status pracuje & & 1 & 0,235 & & & \\
\hline Dochód (PLN) & & & 1 & & & \\
\hline Dochód (euro) & & & & 1 & 0,205 & \\
\hline 3.1. Termin & & & & & & 1 \\
\hline 3.7. Czas & & & & & & \\
\hline
\end{tabular}

Źródło: opracowanie własne z użyciem pakietu SAS. 
Bartletta (tab. 15) sugeruje, że można odrzucić hipotezę, iż macierz korelacji jest jednostkowa na poziomie istotności mniejszym niż 0,05 , co oznacza, że zmienne nie są niezależne względem siebie i w zbiorze danych istnieją czynniki wspólne (Zakrzewska, 1994).

Tabela 15. Wartość współczynników w teście sferyczności Bartletta

\begin{tabular}{|c|c|c|c|}
\cline { 2 - 4 } \multicolumn{1}{c|}{} & \multicolumn{3}{c|}{ Test sferyczności Bartletta } \\
\cline { 2 - 4 } \multicolumn{1}{c|}{} & chi kwadrat & $\begin{array}{c}\text { stopnie } \\
\text { swobody }\end{array}$ & wartość $p$ \\
\hline 1 & 8869,850 & 253 & 0,0000 \\
\hline
\end{tabular}

Źródło: opracowanie własne przy użyciu pakietu STATISTICA.

W przeprowadzonej analizie otrzymano pięć czynników wspólnych o wartości własnej większej od jedności przy 16 zmiennych (5/16), co spełnia kryterium Kaisera odnośnie do liczby czynników wspólnych koniecznych i wystarczających do wytłumaczenia interkorelacji grupy zmiennych ${ }^{5}$. Z uwagi na zbyt dużą liczbę wyróżnionych składowych, które wyjaśniłyby zalecane w literaturze 75\% wariancji zmiennych (Zakrzewska, 1994), mając na celu uniknięcie problemów $z$ interpretacją zanadto rozbudowanej struktury czynnikowej, zastosowano kryterium $50 \%$ wariancji i wyodrębniono pięć czynników wspólnych (tab. 16). Wyróżnienie pięciu czynników wspólnych jest uzasadnione testem scree wartości własnej charakteryzującej poszczególne składowe (rys. 1). Przy zachowaniu pewnej dozy ostrożności można na ich podstawie wnioskować o badanej zbiorowości.

W analizie nasycenia wyróżnionych czynników poszczególnymi zmiennymi pierwotnymi (tab. 17) jako istotne dla ładunku czynnika wartości wyższej lub bardzo bliskiej traktowano wartości 0,5 (Zakrzewska, 1994).

Uzyskane czynniki zinterpretowano oraz uporządkowano w kolejności od najsilniej do najsłabiej różnicu-
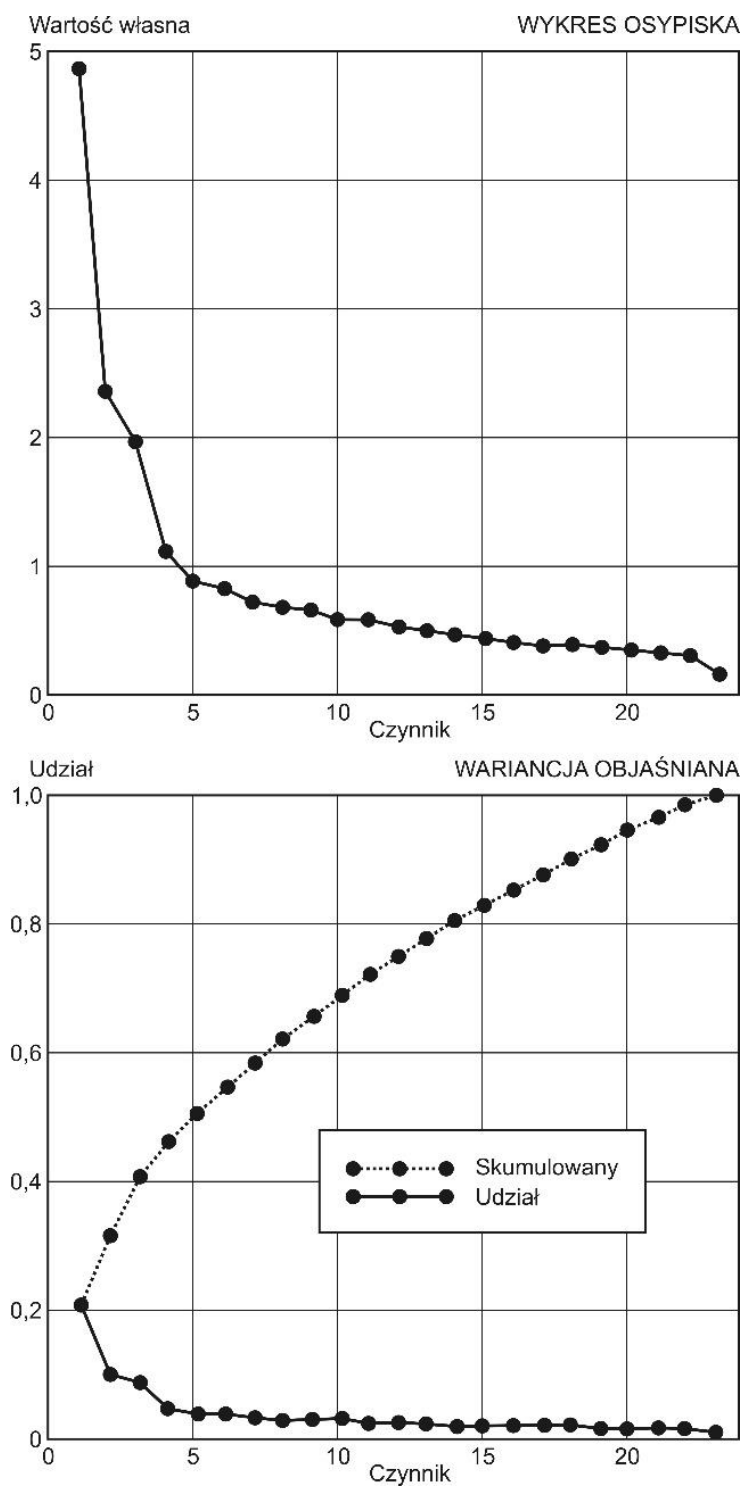

Rysunek 1. Wykres osypiska / test scree Źródło: opracowanie własne z użyciem SAS

Tabela 16. Wartości własne macierzy korelacji

\begin{tabular}{|c|c|c|c|c|}
\hline \multirow{2}{*}{ Składowe } & \multicolumn{3}{|c|}{ Wartości własne macierzy korelacji: łącznie = 23, średnio =1 } \\
\cline { 2 - 5 } & wartość własna & różnica & udział & skumulowany \\
\hline 1 & 4,897 & 2,442 & 0,213 & 0,213 \\
\hline 2 & 2,455 & 0,389 & 0,107 & 0,320 \\
\hline 3 & 2,066 & 0,815 & 0,090 & 0,410 \\
\hline 4 & 1,251 & 0,225 & 0,054 & 0,464 \\
\hline 5 & 1,026 & 0,060 & 0,045 & 0,509 \\
\hline 6 & 0,966 & 0,110 & 0,042 & 0,551 \\
\hline 7 & 0,856 & 0,039 & 0,037 & 0,588 \\
\hline 8 & 0,817 & 0,010 & 0,036 & 0,623 \\
\hline 9 & 0,807 & 0,060 & 0,035 & 0,658 \\
\hline 10 & 0,746 & 0,028 & 0,032 & $\ldots, 691$ \\
\hline
\end{tabular}

Źródło: opracowanie własne z użyciem pakietu SAS. 
Tabela 17. Obrócony układ czynników metodą „ortogonalny varimax"

\begin{tabular}{|l|c|c|c|c|c|}
\hline \multicolumn{1}{|c|}{ Obrócony układ czynników } \\
\hline & czynnik 1. & czynnik 2. & czynnik 3. & czynnik 4. & czynnik 5. \\
\hline Stnd_8.2. przyroda & $\mathbf{0 , 7 9 7}$ & 0,170 & 0,078 & 0,037 & $-0,016$ \\
\hline Stnd_8.4. kultura & $\mathbf{0 , 7 8 2}$ & 0,067 & 0,087 & 0,170 & $-0,118$ \\
\hline Stnd_8.5. imprezy & $\mathbf{0 , 7 7 5}$ & 0,095 & 0,046 & 0,129 & 0,045 \\
\hline Stnd_8.3. rozrywka & $\mathbf{0 , 7 3 6}$ & 0,105 & 0,040 & 0,026 & 0,154 \\
\hline Stnd_8.1. rekreacja, sport & $\mathbf{0 , 6 4 5}$ & 0,164 & 0,016 & $-0,007$ & 0,223 \\
\hline Stnd_3.3. bhp & 0,135 & $\mathbf{0 , 7 1 0}$ & $-0,013$ & 0,039 & 0,153 \\
\hline Stnd_3.4. promocja & 0,149 & $\mathbf{0 , 6 8 2}$ & 0,014 & $-0,021$ & 0,088 \\
\hline Stnd_3.6. oferta & 0,182 & $\mathbf{0 , 6 6 5}$ & 0,046 & $-0,019$ & 0,249 \\
\hline Stnd_3.1. termin & 0,132 & $\mathbf{0 , 6 5 0}$ & 0,173 & $-0,036$ & $-0,005$ \\
\hline Stnd_3.7. czas & $-0,018$ & $\mathbf{0 , 5 8 2}$ & 0,205 & 0,024 & $-0,201$ \\
\hline Stnd_3.2. koszty & 0,080 & $\mathbf{0 , 5 3 8}$ & 0,041 & 0,153 & $-0,145$ \\
\hline Stnd_3.5. zakup & 0,013 & $\mathbf{0 , 4 9 6}$ & 0,058 & 0,032 & 0,280 \\
\hline Stnd_7.1. rodzaj & 0,077 & 0,079 & $\mathbf{0 , 7 3 2}$ & 0,056 & 0,008 \\
\hline Stnd_7.3. marka & 0,005 & 0,124 & $\mathbf{0 , 6 8 3}$ & 0,064 & 0,102 \\
\hline Stnd_7.2. walka & 0,054 & 0,034 & $\mathbf{0 , 6 6 1}$ & 0,233 & $-0,040$ \\
\hline Stnd_7.8. poziom & 0,024 & 0,040 & $\mathbf{0 , 6 2 6}$ & 0,083 & 0,300 \\
\hline Stnd_7.7. stawka & 0,050 & 0,115 & $\mathbf{0 , 5 7 0}$ & $-0,030$ & 0,442 \\
\hline Stnd_7.11. miejsce & 0,124 & 0,169 & 0,363 & 0,290 & $-0,083$ \\
\hline Stnd_7.4. relaks & 0,081 & 0,100 & 0,130 & $\mathbf{0 , 7 1 0}$ & 0,036 \\
\hline Stnd_7.5. na żywo & 0,028 & $-0,116$ & 0,140 & $\mathbf{0 , 7 0 4}$ & 0,058 \\
\hline Stnd_7.10. rodzina & 0,131 & 0,101 & 0,077 & $\mathbf{0 , 6 8 4}$ & 0,206 \\
\hline Stnd_7.6. prestiż & 0,152 & 0,174 & 0,132 & 0,164 & $\mathbf{0 , 7 0 0}$ \\
\hline Stnd_7.9. gwiazda & 0,093 & $-0,036$ & 0,329 & 0,323 & $\mathbf{0 , 4 9 4}$ \\
\hline
\end{tabular}

Objaśnienia: wytłuszczenie cyfr wartości współczynników korelacji większych lub bardzo bliskich 0,5.

Źródło: opracowanie własne z użyciem pakietu SAS.

Tabela 18. Interpretacja pięcioelementowego modelu czynników wyjaśniających skłonność badanych kibiców do udziału w wydarzeniach sportowych

\begin{tabular}{|c|c|c|c|}
\hline Czynnik & $\begin{array}{l}\text { Zmienne } \\
\text { nasycone }\end{array}$ & Opis & Interpretacja \\
\hline 1. & $\begin{array}{l}\text { 8.1. Rekreacja, sport } \\
\text { 8.2. Przyroda } \\
\text { 8.3. Rozrywka } \\
\text { 8.4. Kultura } \\
\text { 8.5. Imprezy } \\
\end{array}$ & $\begin{array}{l}\text { Imprezy dodatkowe } \\
\text { Atrakcje kulturowe } \\
\text { Oferta rozrywkowa } \\
\text { Atrakcje przyrodnicze } \\
\text { Rekreacja fizyczna, sport } \\
\end{array}$ & $\begin{array}{l}\text { Dostępność dodatkowych usług (atrakcji } \\
\text { turystycznych) towarzyszących wyjazdowi } \\
\text { na mecz }\end{array}$ \\
\hline 2. & $\begin{array}{l}\text { 3.1. Termin } \\
\text { 3.2. Koszty } \\
\text { 3.3. Bhp } \\
\text { 3.4. Promocja } \\
\text { 3.5. zakup } \\
\text { 3.6. Oferta } \\
\text { 3.7. Czas }\end{array}$ & $\begin{array}{l}\text { Terminy meczów ograniczają kibicowanie } \\
\text { Koszty wyjazdu na mecze siatkówki } \\
\text { Obawa o bezpieczeństwo podczas wyjazdu i meczu } \\
\text { Niewłaściwa promocja meczów reprezentacyjnych } \\
\text { Kupno biletów na mecze } \\
\text { Oferta na meczach } \\
\text { Brak wolnego czasu }\end{array}$ & Bariery \\
\hline 3. & $\begin{array}{l}\text { 7.1. Rodzaj } \\
\text { 7.2. Walka } \\
\text { 7.3. Marka } \\
\text { 7.7. Stawka } \\
\text { 7.8. Poziom }\end{array}$ & $\begin{array}{l}\text { Rodzaj rozgrywek } \\
\text { Zaciętość walki sportowej } \\
\text { Marka drużyn } \\
\text { Stawka meczu } \\
\text { Poziom sportowy }\end{array}$ & $\begin{array}{l}\text { Atrakcyjność widowiska sportowego z punk- } \\
\text { tu widzenia jego poziomu sportowego }\end{array}$ \\
\hline 4. & $\begin{array}{l}\text { 7.4. Relaks } \\
\text { 7.5. Na żywo } \\
\text { 7.10. Rodzina } \\
\end{array}$ & $\begin{array}{l}\text { Relaks } \\
\text { Oglądanie „na żywo” } \\
\text { Wyjście rodzinne }\end{array}$ & $\begin{array}{l}\text { Funkcja rekreacyjna widowiska - atrakcyj- } \\
\text { nie spędzony czas wolny z rodziną }\end{array}$ \\
\hline 5. & \begin{tabular}{|l|} 
7.6. Prestiż \\
7.9. Gwiazda
\end{tabular} & $\begin{array}{l}\text { Prestiż bycia kibicem } \\
\text { Możliwość obejrzenia gwiazdy sportu }\end{array}$ & Prestiż - odczuwanie prestiżu widowiska \\
\hline
\end{tabular}

Źródło: opracowanie własne. 
jącego daną zbiorowość (tab. 18). Uzyskano pięcioelementowy model czynników wyjaśniających skłonność badanych kibiców do udziału $\mathrm{w}$ wydarzeniach sportowych.

\section{ZAKOŃCZENIE I WNIOSKI}

Na podstawie przedstawionych wyników badań można zweryfikować postawione $\mathrm{w}$ procesie badawczym hipotezy (tab. 19).

Tabela 19. Weryfikacja postawionych hipotez

\begin{tabular}{|c|l|}
\hline Hipoteza & \multicolumn{1}{|c|}{ Weryfikacja hipotezy } \\
\hline 1 & $\begin{array}{l}\text { Zidentyfikowane istotne różnice w postrzeganiu } \\
\text { ważności poszczególnych barier/czynników zarów- } \\
\text { no między badanymi kobietami i mężczyznami, jak } \\
\text { i między kibicami polskimi i pochodzącymi z za- } \\
\text { granicy (tab. 12, 13). }\end{array}$ \\
\hline 2 & $\begin{array}{l}\text { Przeciętne oceny ważności poszczególnych czyn- } \\
\text { ników różnią się, co umożliwia tworzenia list czynni- } \\
\text { ków uporządkowanych według ich ważności - hie- } \\
\text { rarchii (tab. 7, 9, 11). }\end{array}$ \\
\hline 3 & $\begin{array}{l}\text { Oceny ważności czynników uczestnictwa w wyda- } \\
\text { rzeniach sportowych korelują częściowo ze zmien- } \\
\text { nymi opisującymi profil demograficzny badanych } \\
\text { osób (tab. 14). }\end{array}$ \\
\hline 4 & $\begin{array}{l}\text { Badane bariery i czynniki pozwalają na identyfika- } \\
\text { cję około pięciu czynników ukrytych (tab. 18). }\end{array}$ \\
\hline
\end{tabular}

Źródło: opracowanie własne.
Wnioski z weryfikacji hipotez można rozpatrywać z punktu widzenia ich wkładu teoretycznego. W badaniach została ujawniona hierarchia czynników uczestnictwa $w$ wydarzeniach sportowych. Najważniejszym z tych czynników jest reprezentowany przez podskalę utworzoną przez zmienne odpowiedzialne za postrzeganie estetyki i dramaturgii wydarzeń. Można tę podskalę odnieść do wyników uzyskiwanych przez autorów posługujących się skalą MSSC, co przedstawiono w tab. 20.

Porównanie uzyskanych przez autora przeciętnych wartości w zakresie poszczególnych podskal wypracowanego modelu z uzyskanymi przez innych autorów wartościami przeciętnymi poszczególnych podskal MSSC wykazuje kilka podobieństw. Spójna wydaje się wysoka pozycja motywów „dramaturgia" i „osiągnięcia” oraz motywów rodzinnych. Motyw ucieczki widoczny jest zawsze w środku skali. Niejasne jest miejsce spotkań społecznych, które znajdowały się zarówno na początkowych, jak i na końcowych szczeblach hierarchii. Różnice w uzyskiwanych wynikach mogą być efektem różnic między grupami badanych oraz różnic w stosowanej skali badawczej. Wkładem w teorię jest również uzyskany pięcioczynnikowy model udziału w wydarzeniach sportowych (rys. 2, por. tab. 18).

Z uwagi na walory uzyskanego modelu w zakresie jego rzetelności skalę pomiarową zawartą $\mathrm{w}$ kwestionariuszu badawczym można uznać za alternatywny sposób analizowania charakterystyk respondentów, które świadczą o skłonności tych osób do uczestnict-wa w dużych imprezach sportowych. W stosunku do wykorzystywanych już

Tabela 20. Porównanie hierarchii czynników uzyskanych w badaniach własnych z motywami mierzonymi skalą MSSC $\mathrm{w}$ wybranych badaniach przeprowadzonych przez innych naukowców

\begin{tabular}{|c|c|c|c|c|c|c|}
\hline & \multirow[b]{2}{*}{$\begin{array}{l}\text { Badania własne } \\
\quad(\text { wg tab. 8) }\end{array}$} & \multicolumn{5}{|c|}{ Skala MSSC } \\
\hline & & $\begin{array}{c}\text { zmodyfikowane } \\
\text { (wyniki badań) } \\
\mathrm{N}=222 \\
\text { (Ryśnik, Żylak, } \\
\text { Tomik, 2018) } \\
\end{array}$ & $\begin{array}{c}\text { koreańscy kibice } \\
\text { N = 511 } \\
\text { (Won, Kitamura, } \\
\text { 2007) }\end{array}$ & $\begin{array}{c}\text { japońscy kibice } \\
N=593 \\
\text { (Won, Kitamura } \\
2007)\end{array}$ & $\begin{array}{c}\text { gdy gra ulu- } \\
\text { biony gracz } \\
\mathrm{N}=142 \\
\text { (Fink, Parker } \\
\text { 2009) }\end{array}$ & \begin{tabular}{|c} 
gdy nie gra ulu- \\
biony gracz \\
$\mathrm{N}=142$ \\
(Fink, Parker \\
2009) \\
\end{tabular} \\
\hline $\begin{array}{l}\text { Czynniki } \\
\text { według ko- } \\
\text { lejności pod } \\
\text { względem } \\
\text { zmierzonej } \\
\text { wartości } \\
\text { przeciętnej } \\
\text { czynników } \\
\text { lub podskal }\end{array}$ & $\begin{array}{l}\text { 1. Oglądanie na żywo } \\
\text { 2. Rodzaj rozgrywek, } \\
\text { zaciętość walki } \\
\text { sportowej, relaks, } \\
\text { możliwość zobacze- } \\
\text { nia gwiazdy sportu, } \\
\text { wyjście rodzinne } \\
\text { 3. Marka drużyn } \\
\text { 4. Poziom sportowy, } \\
\text { miejsce rozgrywa- } \\
\text { nia meczu } \\
\text { 5. Stawka meczu } \\
\text { 6. Prestiż bycia } \\
\text { kibicem }\end{array}$ & $\begin{array}{l}\text { 1. Estetyka, } \\
\text { dramaturgia } \\
\text { 2. Osiągnięcia } \\
\text { i wiedza } \\
\text { 3. Ucieczka } \\
\text { 4. Spotkanie } \\
\text { 5. Rodzina }\end{array}$ & $\begin{array}{l}\text { 1. Dramaturgia } \\
\text { 2. Osiągnięcia } \\
\text { 3. Rozrywka } \\
\text { 4. Ucieczka } \\
\text { 5. Duma z bycia } \\
\text { w grupie } \\
\text { 6. Rodzina } \\
\text { 7. Umiejętności } \\
\text { 8. Spotkania } \\
\text { społeczne } \\
\text { 9. Atrakcyjność } \\
\text { graczy }\end{array}$ & $\begin{array}{l}\text { 1. Osiągnięcia } \\
\text { 2. Rozrywka } \\
\text { 3. Dramaturgia } \\
\text { 4. Umiejętności } \\
\text { 5. Ucieczka } \\
\text { 6. Duma z bycia } \\
\text { w grupie } \\
\text { 7. Rodzina } \\
\text { 8. Spotkania } \\
\text { społeczne } \\
\text { 9. Atrakcyjność } \\
\text { graczy }\end{array}$ & $\begin{array}{l}\text { 1. Umiejętności } \\
\text { 2. Dramaturgia } \\
\text { 3. Spotkania } \\
\text { 4. Osiągnięcia } \\
\text { 5. Ucieczka } \\
\text { 6. Estetyka } \\
\text { 7. Rodzina } \\
\text { 8. Wiedza } \\
\text { 9. Atrakcyjność } \\
\quad \text { fizyczna }\end{array}$ & $\begin{array}{l}\text { 1. Dramaturgia } \\
\text { 2. Umiejętności } \\
\text { 3. Spotkania } \\
\text { 4. Ucieczka } \\
\text { 5. Estetyka } \\
\text { 6. Rodzina } \\
\text { 7. Wiedza } \\
\text { 8. Osiągnięcia } \\
\text { 9. Atrakcyjność } \\
\text { fizyczna }\end{array}$ \\
\hline
\end{tabular}

Źródło: opracowanie własne na podstawie źródeł podanych w tabeli. 


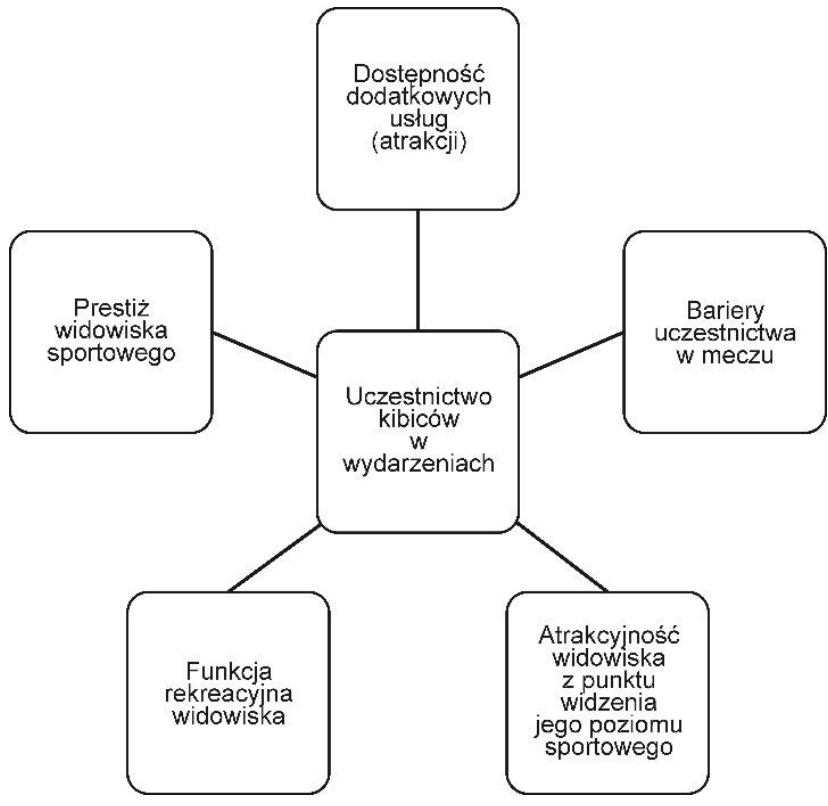

Rysunek 2. Czynniki skłaniające do uczestnictwa kibiców w wydarzeniu sportowym

Źródło: opracowanie własne

w Polsce i za granicą rozwiązań $w$ badaniach kibiców należy zwrócić uwagę na nowość w konstrukcji tej skali. Stanowi ona próbę połączenia klasycznego zestawu czynników stosowanych do badania motywacji kibiców (Funk, Filo, Beaton, Pritchard, 2009; Kim, Trail, 2010; Milne, McDonald, 1999, za: Won, Kitamura, 2007; Neale, Funk
2006; Sloan, 1989; Trail, James, 2001; Wann, 1999, za: Hadzik, 2016) z barierami uczestnictwa (Anthony, Kahn, Madison, Paul, Weinbach, 2014; Mohan, Thomas, 2012; Nishio 2014; Simmons, Popp, McEvoy, Howell, 2018; Yu, 2010), co upodabnia go ideowo do syntetycznego podejścia zastosowanego przez Kima i Traila (2010). Jednocześnie jest próbą poszukiwania swoistej „wspólnej przestrzeni", tworzącej się na styku sportu i turystyki (Szczechowicz, 2015), poprzez dołączenie do modelu kwestii związanych z wartością użytkową kontekstu wydarzenia, w postaci np. imprez rozrywkowych czy produktów turystycznych. Uzyskane wyniki potwierdzają, że turystyka i sport to zjawiska, które mogą i powinny być badane razem.

\section{WSKAZANIA DLA PRAKTYKÓW}

Wnioski z weryfikacji hipotez można rozpatrywać pod kątem użyteczności dla menadżerów podmiotów odpowiedzialnych za kształtowanie produktów w turystyce sportowej. Sformułowano postulaty dotyczące praktyki zarządzania dużymi wydarzeniami sportowymi, mające na celu dopasowanie ich do preferencji podróżujących kibiców (tab. 21).

Posłużenie się wskazówkami i postulatami zebranymi w tab. 19 powinno sprzyjać uczestnictwu kibiców w wielkich wydarzeniach sportowych.

Tabela 21. Wnioski praktyczne wysnute na podstawie kierunku weryfikacji postawionych hipotez

\begin{tabular}{|c|c|c|}
\hline Nr hipotezy & Weryfikacja hipotezy & Wniosek dla praktyki \\
\hline 1 & $\begin{array}{l}\text { Zidentyfikowano istotne różnice } \\
\text { w postrzeganiu ważności po- } \\
\text { szczególnych barier/czynników } \\
\text { zarówno pomiędzy badanymi ko- } \\
\text { bietami i mężczyznami, jak i po- } \\
\text { między kibicami polskimi i pocho- } \\
\text { dzącymi z zagranicy (tab. 14, 15). }\end{array}$ & $\begin{array}{l}\text { Należy zróżnicować oferty i rozkład akcentów w przekazie promującym dane wy- } \\
\text { darzenie z uwagi na grupę docelową (płeć, pochodzenie). } \\
\text { 1) W przypadku oferty oraz przekazu promocyjnego, które są skierowane do męż- } \\
\text { czyzn, należy w większym stopniu skupiać się na akcentowaniu: } \\
\text { - dogodności terminów i dostępności miejsca danego wydarzenia, } \\
\text { - rangi i poziomu sportowego wydarzenia, } \\
\text { - dostępności dodatkowych imprez rozrywkowych. } \\
\text { 2) W przypadku oferty i przekazu promocyjnego, które są skierowane do kobiet, } \\
\text { powinno się w większym stopniu podkreślać: } \\
\text { - cenową atrakcyjność wydarzenia; } \\
\text { - poziom relaksacji związany z wydarzeniem; } \\
\text { - prestiż wydarzenia; } \\
\text { - dostępność w pakiecie innych imprez dodatkowych, angażujących kibiców } \\
\text { w zakresie rekreacji fizycznej oraz sportu. } \\
\text { 3) W przypadku oferty i promocji, które są skierowane do osób z zagranicy, należy } \\
\text { szczególnie skupiać się na: } \\
\text { - bezpieczeństwie imprezy, } \\
\text { - wysokiej jakości informacji o imprezie, } \\
\text { - dostępie do dodatkowych usług w samym obiekcie rozgrywania meczu, } \\
\text { - dostępności atrakcji kulturalnych oraz przyrodniczych. } \\
\text { 4) W przypadku oferty i promocji, które są skierowane do osób w kraju powinno } \\
\text { się akcentować: } \\
\text { - atrakcyjność kosztową; } \\
\text { - poziom sportowy; } \\
\text { - oglądanie na żywo, obcowanie z gwiazdami sportu; } \\
\text { - } \text { możliwość relaksu z rodziną. }\end{array}$ \\
\hline
\end{tabular}


Tabela $21(\mathrm{~cd}$.)

\begin{tabular}{|c|c|c|}
\hline Nr hipotezy & Weryfikacja hipotezy & Wniosek dla praktyki \\
\hline 2 & $\begin{array}{l}\text { Przeciętne oceny ważności poszcze- } \\
\text { gólnych czynników różnią się, co } \\
\text { umożliwia tworzenie list czynni- } \\
\text { ków uporządkowanych według ich } \\
\text { ważności - hierarchii (tab. 9,11,13). }\end{array}$ & $\begin{array}{l}\text { 1) Skupiając się na dwóch najistotniejszych barierach dla kibiców, w budowaniu } \\
\text { oferty i formułowaniu promocji należy w pierwszej kolejności zwrócić uwagę na } \\
\text { niwelację niedogodności związanych z kosztami uczestnictwa w imprezie spor- } \\
\text { towej oraz poświęconym na to czasem (tab. 9). } \\
\text { 2) Czynniki oceniane jako najistotniejsze wskazują na konieczność szczególnego } \\
\text { potraktowania (tab. 11, 13): } \\
\text { - waloru oglądania wydarzenia na żywo (autentyczności i unikatowości wy- } \\
\text { darzenia oraz możliwości obcowania z gwiazdami sportu), } \\
\text { - poziomu sportowego wydarzenia, } \\
\text { - walorów sprzyjających relaksacji w gronie rodzinnym. }\end{array}$ \\
\hline 3 & $\begin{array}{l}\text { Niektóre oceny ważności czynni- } \\
\text { ków uczestnictwa w wydarzeniach } \\
\text { sportowych korelują ze zmienny- } \\
\text { mi opisującymi profil demogra- } \\
\text { ficzny badanych osób (tab. 16). }\end{array}$ & $\begin{array}{l}\text { Organizatorzy wydarzeń powinni być świadomi, że przyciągnięcie starszego i bar- } \\
\text { dziej zamożnego kibica sportowego wymaga zmierzenia się z barierami braku } \\
\text { czasu oraz problemem ustalenia dogodnego terminu wydarzenia. Stąd wymagany } \\
\text { jest dobór jak najlepszego terminu dla danej grupy docelowej albo wprowadzenie } \\
\text { różnorodnych udogodnień oszczędzających czas, co sprawi, że będzie on lepiej wy- } \\
\text { korzystany. }\end{array}$ \\
\hline 4 & $\begin{array}{l}\text { Badane bariery i czynniki pozwa- } \\
\text { lają na identyfikację około pięciu } \\
\text { czynników ukrytych (tab. 20). }\end{array}$ & $\begin{array}{l}\text { Uzyskany model jest wskazówką dla menedżerów, jak w procesie percepcji trakto- } \\
\text { wane są przez kibiców poszczególne cechy wydarzenia. } \\
\text { 1) W umyśle kibica zmienne wchodzące w skład danego czynnika wspólnego mogą } \\
\text { być traktowane łącznie, co oznacza, że w zakresie poszczególnych zmiennych } \\
\text { występuje substytucja. } \\
\text { 2) Subsytucja nie występuje jednak między zmiennymi tworzącymi różne czynniki } \\
\text { wspólne. } \\
\text { Menadżerowie powinni traktować rozłącznie wysiłki/efekty działań skierowanych } \\
\text { na różne elementy modelu (w zakresie zmiennych z różnych czynników nie wystę- } \\
\text { puje substytucja). Na przykład niwelując bariery, nie można zrekompensować kibi- } \\
\text { cowi niskiego poziomu sportowego. Menedżerowie powinni czynić równoległe wy- } \\
\text { siłki w zakresie: } \\
\text { - dostępności dodatkowych usług, imprez, atrakcji; } \\
\text { - niwelowania barier; } \\
\text { - zwiększenia atrakcyjności widowiska sportowego z uwagi na poziom spor- } \\
\quad \text { towy; } \\
\text { - podniesienie atrakcyjności widowiska dla poszukujących relaksu i czasu miło } \\
\text { spędzonego z rodziną; } \\
\text { - budowania prestiżu kibicowania podczas wydarzenia sportowego oraz zaan- } \\
\quad \text { gażowania gwiazd sportu w dane wydarzenie. }\end{array}$ \\
\hline
\end{tabular}

Źródło: opracowanie własne.

\section{PRZYPISY}

1 „Popyt turystyczny może być rozumiany jako suma dóbr turystycznych, usług i towarów, które turyści są skłonni nabyć przy określonym poziomie cen i w danym okresie" (Niezgoda, Zmyślony, 2006, za: Kachniewska, Nawrocka, Niezgoda, Pawlicz, 2012, s. 31).

${ }^{2}$ Niektóre wyniki badań opierające się na niepełnej próbie $(\mathrm{N}=434)$ zostały opublikowane $\mathrm{w}$ artykule Hadzika, Ryśnika i Tomika (2015).

${ }^{3}$ Łączna, szacowana na podstawie danych Polskiego Związku Piłki Siatkowej, frekwencja kibiców na meczach faz I, II i III, rozgrywanych $\mathrm{w}$ katowickim Spodku, podczas których były przeprowadzane badania.

4 „KMO mniejszy niż 0,5 - bardzo niski (nie do przyjęcia)” (Zakrzewska, 1994, s. 55).

${ }^{5}$ Liczba ta powinna znajdować się w zakresie od 1/6 do 1/3 ogólnej liczby badanych zmiennych (Zakrzewska, 1994).

\section{BIBLIOGRAFIA}

Ahn, S.C., Lee, Y.H. (2014). Major league baseball attendance: Longterm analysis using factor models. Journal of Sports Economics, 15 (5), 451-477. DOI: https://doi.org/10.1177/1527002514535171

Anthony, T., Kahn, T., Madison, B., Paul, R., Weinbach, A. (2014). Similarities in fan preferences for minor-league baseball across the American Southeast, Journal of Economics \& Finance, 38 (1), 150-163. DOI: https://doi.org/10.1007/s12197-011-9214-7

Fairley, S. (2009). The role of the mode of transport in the identity maintenance of sport fan travel groups. Journal of Sport $\mathcal{E}$ Tourism, 14 (2-3), 205-222. Pobrane z: https:/ / doi.org/ $10.1080 / 14775080902965231$

Fink, J.S., Parker, H.M. (2009). Spectator motives: Why do we watch when our favorite team is not playing? Sport Marketing Quarterly, 18, 210-217.

Fink, J.S., Trail, G.T., Anderson D.F. (2002). Environmental factors associated with spectator attendance and sport consumption 
behavior: Gender and team differences. Sport Marketing Quarterly, 11, 8-19.

Funk, D.C., Filo, K., Beaton, A.A., Pritchard, M. (2009). Measuring the motives of sport event attendance: Bridging the academicpractitioner divide to understanding behaviour. Sport Marketing Quarterly, 18 (3), 126-138.

Hadzik, A. (2014). Turystyka sportowa ze szczególnym uwzględnieniem międzynarodowych widowisk sportowych. Katowice: Akademia Wychowania Fizycznego w Katowicach.

Hadzik, A. (2016). Uwarunkowania rekreacyjnego uczestnictwa w sporcie kibiców międzynarodowych widowisk sportowych. Kraków: European Association For Security.

Hadzik, A., Bartík, P. (2012). The chosen factors of participating in international sports events on the example of football, basketball and volleyball games in Poland. Exercitatio Corpolis-MotusSalus. Slovak Journal of Sport Sciences, 14-149.

Hadzik, A., Ryśnik, J., Tomik, R. (2015). Determinanty uczestnictwa w międzynarodowych widowiskach sportowych: w świetle wyników badań. Prace Naukowe Uniwersytetu Ekonomicznego we Wroctawiu, 379, 75-86. DOI: http:/ / doi.org/10.15611/pn. 2015.379.07

Kachniewska, M., Nawrocka, E., Niezgoda, A., Pawlicz, A. (2012). Rynek turystyczny. Ekonomiczne zagadnienia turystyki. Warszawa: Wolters Kluwer Polska Sp. z o.o..

Kaczmarek, J., Stasiak, A., Włodarczyk, B. (2010). Produkt turystyczny. Pomyst, organizacja, zarzadzanie. Warszawa: Polskie Wydawnictwo Ekonomiczne.

Kazimierczak, M., Malchrowicz-Mośko, E. (2013). Turystyka sportowa - specyfika i trendy rozwojowe. Folia Turistica, 28 (1), 67-90

Kemper, C., Breuer, C. (2015). What factors determine the fans willingness to pay for Bundesliga tickets? An analysis of ticket sales in the secondary market using data from ebay.de. Sport Marketing Quarterly, 24 (3), 142-158.

Kim, Y.K., Trail, G.T. (2010). Constraints and motivators: A new model to explain consumer behaviour. Journal of Sport Management, 24, 190-210. DOI: https:/ / doi.org/10.1123/jsm.24.2.190.

Klisiński, J. (2011). Rynek dóbr i ustug sportowych. Bielsko-Biała: Wydawnictwo Naukowe ATH.

Kramer, J. (1997). Konsumpcja w gospodarce rynkowej. Warszawa: Polskie Wydawnictwo Ekonomiczne.

Kruger, M., Saayman, M. (2012). Why do fans attend world wrestling entertainment? South African Journal for Research in Sport, Physical Education \& Recreation", 34 (2), 63-81.

Milne, G.R., McDonald, M.A. (1999). Sport marketing: Managing the exchange process. Sudbury, MA: Jones and Bartlett Publishers.

Mohan, L., Thomas, L. (2012). The impact of distance on fans' intentions to attend team sporting events: a case study of fans of the Carolina Hurricanes of the United States National Hockey League. Annals of Leisure Research, 15 (3), 296-309. DOI: https://doi.org/10.1080/11745398.2012.693041

Neale, L., Funk, D. (2006). Investigating motivation, attitudinal loyalty and attendance behaviour with fans of Australian football. International Journal of Sports Marketing \& Sponsorship, $7(4), 307-317$.

Nishio, T. (2014). The constraint factors of potential international sports fan tourists. Journal of Vacation Marketing, 20 (2), 137-147. DOI: https://doi.org/10.1177/1356766713496420

Pilarczyk, B., Mruk, H. (2006). Kompendium wiedzy o marketingu. Warszawa: Wydawnictwo Naukowe PWN.

Pitts, B.G. , Stotlar, D.K. (2002). Fundamentals of sport marketing. Morgantown: Fitness Information Technology.

Robinson, M., Trail, G.T. (2005). Relationships among spectator gender, motives and points of attachment in selected intercollegiate sports. Journal of Sport Management, 19, 58-80. DOI: https://doi.org/10.1123/jsm.19.1.58
Ryśnik, J., Żylak, D., Tomik, R. (2018). Propozycja skali pomiarowej motywacji kibiców do konsumpcji turystyki sportowej. Raport z badań pilotażowych. Folia Turistica, 48, 87-116. DOI: http://doi.org/10.5604/01.3001.0012.7693

Shapiro, S.L., Drayer, J. (2014). An examination of dynamic ticket pricing and secondary market price determinants in Major League Baseball. Sport Management Review, 17, 145-159.

Simmons, J.M., Popp, N.K., McEvoy, C.D., Howell S.M. (2018). Using fan passion to investigate constraints to student attendance at college football games. Journal of Intercollegiate Sport, 11 (2), 193-213.

Sloan, L.R. (1989). The motives of sports fans. W: J.H. Goldstein (red.), Sports, games, and play: Social \& psychological viewpoints (s. 175- 240). Wyd. 2. Hillsdale, NJ: Lawrence Erlbaum Associates.

Smith, A.C.T., Stewart, B. (2007). The travelling fan: Understanding the mechanisms of sport fan consumption in a sport tourism setting. Journal of Sport \& Tourism, 12, 3-4, 155-181. DOI: https:/doi.org/10.1080/14775080701736924

Standeven, J., De Knop, P. (1999). Sport tourism. Champaign: Human Kinetics.

Steczkowski, J. (1995). Metoda reprezentacyjna w badaniach zjawisk ekonomiczno-społecznych. Warszawa: PWN.

Surdam, D.G. (2009). What brings fans to the ball park? Evidence from New York Yankees' and Philadelphia Phillies' Financial Records. Journal of Economics, 35, 1, (0361-6576), (s. 1.), s. 35.

Szczechowicz, B. (2015). Łączenie wartości turystyki i sportu w świetle analizy ofert rynkowych. W: M. Kazimierczak (red.), Turystyka sportowa. Społeczno-kulturowy potencjat i perspektywy rozwoju (s. 41-54). Poznań: Wydawnictwo Akademii Wychowania Fizycznego.

Trail, G.T., Anderson, D.F., Fink, J.S. (2002). Examination of gender differences in importance and satisfaction with venue factors at intercollegiate basketball games: Effects on future spectator attendance. International Sports Journal, 6, 51-64.

Trail, G.T., Fink, J.S., Anderson, D.F. (2003). Sport spectator consumption behaviour. Sport Marketing Quarterly, 12, 8-17.

Trail, G.T., James, J.D. (2001). The motivation scale for sport consumption: Assessment of the scale's psychometric properties. Journal of Sport Behaviour, 24 (1), 108-127.

Weed, M., Bull, C. (2004). Sports tourism: Participants, policy and providers, Oxford: Elsevier.

Wojdakowski, P. (2008). Bariery uczestnictwa turystów sportowych w meczach pitki nożnej. W: W.W. Gaworecki, Z. Mroczyński (red.), Turystyka $i$ sport dla wszystkich w promocji zdrowego stylu życia. Gdańsk: Wyższa Szkoła Turystyki i Hotelarstwa w Gdańsku.

Wojdakowski, P. (2011). Determinanty uczestnictwa turystów sportowych w meczach piłki nożnej. Praca doktorska. Częstochowa: Politechnika Częstochowska.

Won, J., Kitamura, K. (2007). Comparative analysis of sport consumer motivations between South Korea and Japan. Sport Marketing Quarterly, 16, 93-105.

$\mathrm{Yu}$, C.C. (2010). Factors that influence international fans' intention to travel to the United States for sport tourism. Journal of Sport \& Tourism, 15 (2), 111-137. DOI: https://doi.org/10. $1080 / 14775085.2010 .498249$

Zakrzewska, M. (1994). Analiza czynnikowa w budowaniu i sprawdzaniu modeli psychologicznych. Poznań: Wydawnictwo Naukowe UAM.

Artykuł wpłynął: 16 kwietnia $2019 \mathrm{r}$ Zaakceptowano do druku: 7 czerwca 2019 r 